\title{
Aurora Kinase Inhibitor AMG 900
}

National Cancer Institute

\section{Source}

National Cancer Institute. Aurora Kinase Inhibitor AMG 900. NCI Thesaurus. Code C82349.

A small-molecule inhibitor of Aurora kinases A, B and C with potential antineoplastic activity. Aurora kinase inhibitor AMG 900 selectively binds to and inhibits the activities of Aurora kinases A, B and C, which may result in inhibition of cellular division and proliferation in tumor cells that overexpress these kinases. Aurora kinases are serinethreonine kinases that play essential roles in mitotic checkpoint control during mitosis and are overexpressed by a wide variety of cancer cell types. 